\title{
First successful domestication of a white strain of Auricularia cornea from Thailand
}

\author{
Bandara $\mathbf{A R}^{1,2,3,4}$, Mortimer $\mathbf{P E}^{1,2}$, Vadthanarat $\mathrm{S}^{5}$, Xingrong $\mathbf{P}^{1}$, \\ Karunarathna $\mathrm{SC}^{1,2,6}$, Hyde $\mathrm{KD}^{1,3,4,6^{*}}$, Kakumyan $\mathrm{P}^{3,4}, \mathrm{Xu} \mathrm{J}^{1,2,6^{*}}$
}

${ }^{1}$ CAS Key Laboratory for Plant Diversity and Biogeography of East Asia, Kunming Institute of Botany, Chinese Academy of Sciences, Kunming 650201, Yunnan, China

${ }^{2}$ Centre for Mountain Futures, Kunming Institute of Botany, Kunming 650201, Yunnan, China

${ }^{3}$ Center of Excellence in Fungal Research, Mae Fah Luang University, Chiang Rai 57100, Thailand

${ }^{4}$ School of science, Mae Fah Luang University, Chiang Rai 57100, Thailand

${ }^{5}$ Department of Biology, Faculty of Science, Chiang Mai University, Chiang Mai 50200, Thailand

${ }^{6}$ World Agroforestry Centre, East and Central Asia, Kunming 650201, Yunnan, China

Bandara AR, Mortimer PE, Vadthanarat S, Xingrong P, Karunarathna SC, Hyde KD, Kakumyan P, Xu J 2020 - First successful domestication of a white strain of Auricularia cornea from Thailand. Studies in Fungi 5(1), 420-434, Doi 10.5943/sif/5/1/23

\begin{abstract}
Intraspecies colour variations in cultivated edible mushrooms present novel and potentially valuable alternatives to the research and cultivation industries. In this study, we collected, identified, and domesticated a white strain of Auricularia cornea from Thailand. The brown strain of A. cornea is one of the top two species of Auricularia cultivated and traded in Asia. Since both white and brown phenotypes of $A$. cornea belong to a single species, we established their similarities or differences. Both morphological characteristics and phylogenetic analysis of ITS rDNA sequence data were used to confirm the taxonomic placement of the white $A$. cornea strain in the same clade with the brown $A$. cornea. Nutritional analysis showed that fat, fiber, protein, and total soluble sugar contents of the white A. cornea were significantly higher than the commercially used brown strain. The melanin content of the white strain of $A$. cornea (less than $1.5 \mathrm{mg} / 100 \mathrm{~g}$ ) was not significantly different from that of the brown strain. This discovery may create new opportunities for the mushroom growing industry and for smallholder farmers in Asia.
\end{abstract}

Key words - colour variation - Melanin - Southeast Asia - wood-ear mushrooms

\section{Introduction}

Intraspecies colour variations of cultivated edible mushroom species determine their commercial potentiality. The colour differences among edible mushrooms are also important in identification and edible variability (Williams et al. 2014). For example, the white strain of Agaricus bisporus (Lange) Imbach is more commercially popular than the brown strain (Crimini, Portabella) in the USA. For this reason, the white strain accounted for $87 \%$ of all domestic A. bisporus sales in 2001 (Lucier et al. 2003). Moreover, the white strain and brown strains of $A$. bisporus were shown to possess different nutrient composition (Dikeman et al. 2005, OECD 2007, Phillips et al. 2011).

Among cultivated edible mushrooms, Auricularia Bull. is the third most cultivated mushroom in the world (Royse et al. 2017). Auricularia is known for its high degree of intraspecies colour 
variation, ranging from brown to red (Mau et al. 1998, Lin et al. 2013). Auricularia species have darkly coloured gelatinous basidiomes that are either red (Bandara et al. 2017a) or black (Wu et al. 2014a). Several white strains of Auricularia species have been reported from the wild, such as $A$. auricula (L.) Underw. f. albicans (Berk.) Kobayasi (Kobayashi 1981), A. cornea Ehrenb. (Wong 1989), A. delicata (Fr.) Henn. f. alba (Kobayashi 1981), A. fuscosuccinea (Mont.) Henn. (Sierra et al. 2008), and A. polytricha (Mont.) Sacc. f. leucochroma (Kobayasi) (Kobayashi 1981). Among these white strains of Auricularia, A. auricula (Thaithatgoon et al. 2004) and A. fuscosuccinea (Mau et al. 1998, Lin et al. 2013) were domesticated for commercial purposes. Nutritional analysis has shown that the cultivated white strain of $A$. fuscosuccinea had a higher proportion of fat, fiber, and protein as compared to the brown strain. Moreover, the white A. fuscosuccinea contained lower carbohydrates and reduced sugar levels in comparison with the brown strain (Mau et al. 1998).

Auricularia cornea is an edible mushroom with many medicinal properties (Lowy 1952, Looney et al. 2013). Different ethnic groups have used A. cornea as a traditional medicine for anxiety, fear, and poisoning by plant toxins (Fuller et al. 2005, Lampman 2007). Auricularia cornea is widespread throughout Asia and was originally described from the Asian Pacific region (Looney et al. 2013). Another study had suggested A. cornea's existence in Africa and South America (Wu 2016). Generally, A. cornea produces large basidiomes up to $15 \mathrm{~cm}$ in width (Lowy 1952, Looney et al. 2013). Our previous study published in 2017 identified that $A$. cornea isolated from Thailand has dark brown abhymenial and hymenial surfaces (Bandara et al. 2017b). It was also reported that the black-brown strain of A. cornea has been cultivated in China since 1975 (Zhang et al. 2015).

Commercially cultivated Auricularia species in Asia have been primarily identified as $A$. polytricha (Chang \& Miles 2004, Yan et al. 2004, Yu et al. 2008, Jia et al. 2011, Razak et al. 2013, Wu et al. 2014a). In 2013, A. polytricha was synonymized to A. nigricans (Fr.: Fr.) Birkebak, Looney and Sánchez-García which has been found in the New World (Looney et al. 2013). A previous research study from 2000 proposed that the proper name for the cultivated A. polytricha should be A. cornea, and emphasized the necessity of investigating those species which have been commercially cultivated (Stamets 2000).

Auricularia basidiomes are a rich source of melanin (Zou et al. 2013, Tang \& Shi 2014). Approximately $10 \%$ of the dry mass of A. auricula is known to contain melanin, which is primarily located in the cell wall as dark brown pigments (Prados-Rosales et al. 2015). In comparison, the most abundant mushroom-derived melanin type found in nature, which had been extracted from $A$. auricula, contains eumelanin - a brown to black pigment (Kim et al. 2009, Prados-Rosales et al. 2015, Wu et al. 2018). Melanin isolated from A. auricula also possesses anti-microbial or antibiofilm properties, as illustrated by the inhibition of biofilms formed by Pseudomonas fluorescens P-3, Escherichia coli K-12 and Pseudomonas aeruginosa PAO1 (Bin et al. 2012, Bandara et al. 2019). Melanin is found in many different edible mushrooms (Mendoza et al. 1979, De Souza et al. 2018), and is naturally present in some specific sites, such as the dark mucous mass on the mycelium of Pleurotus cystidiosus var. formosensis (Selvakumar et al. 2008). Moreover, the formation of brown coloured melanin has been observed to cause discolouration of Agaricus bisporus basidiomes (Jolivet et al. 1998). Melanin is a product that has applications in the food industry, as well as pharmacological, medicinal, and cosmetic fields (Sun et al. 2016a).

In this study we hypothesized that the white strain of $A$. cornea would have no or a very low concentration of melanin. In addition to testing the melanin content of our strain of $A$. cornea, we provide a full morphological and molecular description of this Auricularia species. Furthermore, our study includes a description of the successful domestication process, including substrates and growing conditions.

\section{Materials \& Methods}

\section{Sample collection}

The fresh specimens of white A. cornea were collected from a forest in Chiang Mai, Thailand 
on August 2016, and macro and micro morphological descriptions were made at the Center of Excellence in Fungal Diversity in Mae Fah Luang University. The specimens were then dried in an electric food dryer at $40-50^{\circ} \mathrm{C}$ until no more moisture remained, and then sealed in dehydrated silica gel-containing ziplock plastic bags to regulate humidity. The dried specimens in Ziplock bags were then deposited in the Herbarium of Mae Fah Luang University (MFLU).

\section{Morphological characteristics}

Description of macroscopic and microscopic morphological characteristics was done by following the methods described in Bandara et al. (2017b). Fresh materials were photographed in situ with specific notes on colour notions. Microscopic examinations were done using a Nikon Eclipse 80i (Nikon, Tokyo, Japan) microscope with a camera fitted on the top, and image measurements were taken by Image framework software (Tarosoft $\left.{ }^{\circledR}, \mathrm{v} 0.9 .7\right)$.

\section{DNA Extraction, PCR, Sequencing, and Phylogenetic analyses}

DNA extraction from dried basidiomes was done using Biospin Fungus Genomic DNA extraction kit, BSC14S1 (Bioer Technology Co., Ltd. Bio-Tek, Hangzhou, P.R. China). PCR to amplify internal transcribed spacer (ITS) regions of Nuclear Ribosomal DNA (ITS1-5.8S-ITS2) (White et al. 1990) was carried out as per previously described protocols in Bandara et al. (2017b). The ITS (ITS1-5.8S-ITS2) dataset consisted of 100 isolates. The TABLE 1 contains a list of sequences derived from this study (Accession numbers are in bold) as well as those retrieved from the GenBank, they represent 23 taxa including three outgroup taxa [Eichleriella deglubens (FO12006), Exidia recisa (FO12006), and Exidiopsis grisea (RoKi162)]. Phylogenetic analysis was also done as previously described by Bandara et al. (2017b). The aligned dataset comprised of 573 characters including gaps have been submitted to TreeBASE (submission ID: 24583). Maximum likelihood (ML) analysis was performed by raxmlGUI v1.31 using rapid bootstrap analysis with 1000 replicates in the GTR+I+G model (Silvestro \& Michalak 2012). In the ML analysis, bootstrap support $>80$ was considered strong, between $60-80$ was considered moderate, and less than 60 was considered poor.

Table 1 Information of the sequences used in the phylogenetic analyses. Collection numbers of the newly produced sequences and species names of type species are in bold. The country of collection is referred to in parentheses using the first English letter of the country's name following the bold collection number.

\begin{tabular}{|c|c|c|c|c|}
\hline Taxon name & $\begin{array}{l}\text { Herbarium } \\
\text { code }\end{array}$ & $\begin{array}{l}\text { Collection } \\
\text { number }\end{array}$ & $\begin{array}{l}\text { GenBank accession } \\
\text { ITS }\end{array}$ & References \\
\hline $\begin{array}{l}\text { Auricularia } \\
\text { angiospermarum }\end{array}$ & BJFC017274 & Cui12360 & KT152097 & Wu et al. (2015a) \\
\hline A. asiatica & BВH895 & & KX621160 & Bandara et al. (2017b) \\
\hline A. brasiliana & URM85567 & AN-MA 42 & KP729275 & Wu et al. (2015b) \\
\hline A. Americana & & PBM2295 & DQ200918 & Looney et al. (2013) \\
\hline A. auricula-judae & & JT14 & KT152101 & Wu et al. (2015a) \\
\hline A. cornea & TENN066990 & PBM3754 & JX065164 & Looney et al. (2013) \\
\hline A. cornea & PDD103780 & & KR336701 & Bandara et al. (2015) \\
\hline A. cornea & PDD97684 & & KR336700 & Bandara et al. (2015) \\
\hline A. cornea & PDD94825 & & KX621146 & Bandara et al. (2017b) \\
\hline A. cornea & PDD92640 & & KR336699 & Bandara et al. (2015) \\
\hline A. cornea & MFLU162109 & ST10 & KX621143 & Bandara et al. (2017b) \\
\hline A. cornea & MFLU130403 & AB30 & KX621145 & Bandara et al. (2017b) \\
\hline A. cornea & MFLU162108 & AB113 & KX621140 & Bandara et al. (2017b) \\
\hline A. cornea & MFLU162110 & ST14 & KX621141 & Bandara et al. (2017b) \\
\hline A. cornea & MFLU162104 & MRC8 & KX621144 & Bandara et al. (2017b) \\
\hline A. cornea & MFLU162107 & AB51 & KX621142 & Bandara et al. (2017b) \\
\hline A. cornea & LE262938 & & KJ698424 & Malysheva \& Bulakh (2014) \\
\hline A. cornea & LE269791 & & KJ698435 & Malysheva \& Bulakh (2014) \\
\hline
\end{tabular}


Table 1 Continued.

\begin{tabular}{|c|c|c|c|c|}
\hline Taxon name & $\begin{array}{l}\text { Herbarium } \\
\text { code }\end{array}$ & $\begin{array}{l}\text { Collection } \\
\text { number }\end{array}$ & $\begin{array}{l}\text { GenBank accession } \\
\text { ITS }\end{array}$ & References \\
\hline A. cornea & & MFUAB36 & KR336702 & Bandara et al. (2015) \\
\hline A. cornea & & AG1547 & KX022016 & Wu (2016) \\
\hline A. cornea & & Dai12587 & KX022012 & Wu (2016) \\
\hline A. cornea & & Dai13547 & KX022013 & $\mathrm{Wu}(2016)$ \\
\hline A. cornea & & Dai15336 & KX022014 & Wu (2016) \\
\hline A. cornea & & AG6 & KX022015 & Wu (2016) \\
\hline A. cornea & MFLU 190691 & $\operatorname{AB58}(\mathrm{T})$ & MK610683 & This study \\
\hline A. cornea & MFLU 190692 & $\operatorname{AB110}(\mathrm{T})$ & MK610684 & This study \\
\hline A. cornea & MFLU 190693 & $\operatorname{AB111}(\mathrm{T})$ & MK610685 & This study \\
\hline A. cornea & MFLU 190694 & $\operatorname{AB114}(\mathrm{T})$ & MK610686 & This study \\
\hline A. cornea & MFLU 190695 & DSK5 (T) & MK610687 & This study \\
\hline A. cornea & MFLU 190696 & GH09 (I) & MK610687 & This study \\
\hline A. cornea & MFLU 190697 & KUN43 (C) & MK610689 & This study \\
\hline A. cornea & MFLU 190698 & MY01 (M) & MK610690 & This study \\
\hline A. cornea & MFLU 190699 & MY02 (M) & MK610691 & This study \\
\hline A. cornea & MFLU 190700 & MY03 (M) & MK610692 & This study \\
\hline A. cornea & MFLU 190701 & MY04 (M) & MK610693 & This study \\
\hline A. cornea & MFLU130419 & PA109 (P) & MK610694 & This study \\
\hline A. cornea & MFLU 190702 & ST03 $(\mathrm{T})$ & MK610695 & This study \\
\hline A. cornea & MFLU 190703 & ST02 (T) & MK610696 & This study \\
\hline A. cornea & MFLU 190704 & ST01 (T) & MK610697 & This study \\
\hline $\begin{array}{l}\text { A. cornea (white } \\
\text { strain) }\end{array}$ & MFLU 190705 & $\mathbf{V - 1 1}(\mathrm{T})$ & MK610698 & This study \\
\hline A. cornea & MFLU 190706 & VI03 (V) & MK610699 & This study \\
\hline A. cornea & MFLU 190707 & VI05 (V) & MK610700 & This study \\
\hline A. delicata Clade-I & MFLU162112 & MRC7 & KX621149 & Bandara et al. (2017b) \\
\hline A. delicata Clade-I & MFLU162119 & AB104 & KX621147 & Bandara et al. (2017b) \\
\hline A. delicata Clade-II & TENN016963 & AJS1304 & JX065158 & Looney et al. (2013) \\
\hline A. fuscosuccinea & TENN058951 & TFB10743 & JX065141 & Looney et al. (2013) \\
\hline A. heimuer & BJFC & Dai13765 & КМ396793 & Wu et al. (2014b) \\
\hline A. heimuer & & Dai2291 & KM396785 & Wu et al. (2014b) \\
\hline A. heimuer & & Dai11936 & KM396787 & Wu et al. (2014b) \\
\hline A. heimuer & & $2008-2$ & КМ396783 & Wu et al. (2014b) \\
\hline A. heimuеr & & Heishan A & KM396782 & Wu et al. (2014b) \\
\hline A. heimuer & & Dai11935 & КМ396786 & Wu et al. (2014b) \\
\hline A. heimuer & & Cui6137 & KM396784 & Wu et al. (2014b) \\
\hline A. heimuer & & Heishan & KM396778 & Wu et al. (2014b) \\
\hline A. heimuer & & Heishan 2 & KM396779 & Wu et al. (2014b) \\
\hline A. heimuer & & Heishan 3 & KM396780 & Wu et al. (2014b) \\
\hline A. heimuer & & Xiaoheimao & КM396781 & Wu et al. (2014b) \\
\hline A. heimuer & MFLU 190708 & KUN02 (C) & MK610701 & This study \\
\hline A. heimuer & MFLU 190709 & KUN31 (C) & MK610702 & This study \\
\hline A. heimuer & MFLU 190710 & KUN32 (C) & MK610703 & This study \\
\hline A. heimuer & MFLU 190711 & KUN34 (C) & MK610704 & This study \\
\hline A. heimuer & MFLU 190712 & KUN35 (C) & MK610705 & This study \\
\hline A. heimuer & MFLU 190713 & KUN41 (C) & MK610706 & This study \\
\hline A. heimuer & MFLU 190714 & KUN52 (C) & MK610707 & This study \\
\hline A. heimuеr & MFLU 190715 & KUN53 (C) & MK610708 & This study \\
\hline A. heimuer & MFLU 190716 & SK02 (S) & MK610709 & This study \\
\hline A. mesenterica & BRNM706955 & & KP729278 & Wu et al. (2015b) \\
\hline A. minutissima & BJFC017994 & Dai14881 & KT152104 & Wu et al. (2015a) \\
\hline A. nigricans & TENN056825 & TFB4405 & JX065172 & Looney et al. (2013) \\
\hline A. orientalis & BJFC & Dai14875 & KP729270 & Wu et al. (2015b) \\
\hline A. polytricha & & $\mathrm{ZH}$ & HM448450 & Jia et al. (2011) \\
\hline A. polytricha & & 781 & HM448451 & Jia et al. (2011) \\
\hline
\end{tabular}


Table 1 Continued.

\begin{tabular}{|c|c|c|c|c|}
\hline Taxon name & $\begin{array}{l}\text { Herbarium } \\
\text { code }\end{array}$ & $\begin{array}{l}\text { Collection } \\
\text { number }\end{array}$ & $\begin{array}{l}\text { GenBank accession } \\
\text { ITS }\end{array}$ & References \\
\hline A. polytricha & & Shanghai3 & HM448452 & Jia et al. (2011) \\
\hline A. polytricha & & 951 & HM448453 & Jia et al. (2011) \\
\hline A. polytricha & & 243 & HM448454 & Jia et al. (2011) \\
\hline A. polytricha & & Qingyou & HM448455 & Jia et al. (2011) \\
\hline A. polytricha & & Sanyou & HM448456 & Jia et al. (2011) \\
\hline A. polytricha & & Zimuer & HM448457 & Jia et al. (2011) \\
\hline A. polytricha & & Hupo & HM448458 & Jia et al. (2011) \\
\hline A. polytricha & & Au2 & HM448459 & Jia et al. (2011) \\
\hline A. polytricha & & Sumao3 & HM448460 & Jia et al. (2011) \\
\hline A. polytricha & & Chuan er7 & HM448461 & Jia et al. (2011) \\
\hline A. polytricha & & Hongdamuer & HM448462 & Jia et al. (2011) \\
\hline A. polytricha & & Ap1142 & HM448463 & Jia et al. (2011) \\
\hline A. polytricha & & Ap1192 & HM448464 & Jia et al. (2011) \\
\hline A. polytricha & & 3039 & HM448465 & Jia et al. (2011) \\
\hline A. polytricha & & Ap117 & HM448466 & Jia et al. (2011) \\
\hline A. polytricha & & Apw82 & HM448467 & Jia et al. (2011) \\
\hline A. polytricha & & Kang1 & HM448468 & Jia et al. (2011) \\
\hline A. polytricha & & Juer2 & HМ448469 & Jia et al. (2011) \\
\hline A. polytricha & & Shanghai1 & HM448470 & Jia et al. (2011) \\
\hline A. polytricha & & Huang er10 & HM448471 & Jia et al. (2011) \\
\hline A. scissa & TENN059729 & TFB11193 & JX065160 & Looney et al. (2013) \\
\hline A. subglabra & TENN058607 & TFB10499 & JX065155 & Looney et al. (2013) \\
\hline A. thailandica & MFLU130410 & & KR336693 & Bandara et al. (2015) \\
\hline A. tibetica & BJFC017181 & Cui12267 & KT152106 & Wu et al. (2015a) \\
\hline A. villosula & LE 296422 & & KJ698418 & Malysheva \& Bulakh (2014) \\
\hline $\begin{array}{l}\text { Eichleriella } \\
\text { deglubens }\end{array}$ & & FO12006 & AF291272 & Weiß \& Oberwinkler (2001) \\
\hline Exidia recisa & & MW315 & AF291276 & Weiß \& Oberwinkler (2001) \\
\hline Exidiopsis grisea & & RoKi162 & AF291281 & Weiß \& Oberwinkler (2001) \\
\hline
\end{tabular}

(C): China, (I): Indonesia, (M): Myanmar, (P): Philippines, (S): South Korea, (T): Thailand, (V): Vietnam

\section{Isolation, Spawn production, and Basidiome production}

Pure mycelium cultures of the white strain of A. cornea were established from MFLU 190705 (V-11) using tissue culture on potato dextrose agar (PDA) (Oxoid, CM0139). The mycelia were subcultured at $28^{\circ} \mathrm{C}$ for 14 days and transferred to cooked wheat grain and incubated at $28^{\circ} \mathrm{C}$ for three weeks. Basidiomes were produced in plastic bags with Oak (Quercus sp.) sawdust (particle size $\leq 3 \mathrm{~mm}$ ) mixed with rice bran in a 78:20 ratio. Calcium oxide (1\%) and Calcium sulphate (1\%) were added to the mixture and mixed with water until the moisture level reached about $65 \%$. The substrate mixtures were packed ( $1 \mathrm{~kg}$ per bag) tightly in plastic bags and autoclaved at $121^{\circ} \mathrm{C}$ and 15 psi for $4 \mathrm{~h}$. The bags were allowed to cool for $24 \mathrm{~h}$ and then inoculated with $1 \%(\mathrm{w} / \mathrm{w})$ of mycelia colonised rye grains. Inoculated bags were incubated at $28^{\circ} \mathrm{C}$ in the dark. Once the substrate was fully invaded by mycelia, the bags were completely opened. The temperature for the fruiting phase was $28^{\circ} \mathrm{C}$ and the humidity was $85-95 \%$. Mushroom yield was recorded for each flush for 30 bags, which were randomly selected from 200 bags. The biological efficiency of each mushroom bag was calculated using the following equation (Liang et al. 2019).

Biological efficiency (\%) = Yield of fresh basidiome (g)/Substrate dry weight $(\mathrm{g}) \times 100$

Brown strain MFLU 190697 (KUN43) of A. cornea was used as a control for the experiment.

\section{Quantification of nutrient content}

Proximate analysis of the fresh samples of cultivated brown and white strains of A. cornea was carried out as per the standard procedure of the Association of Official Analytical Chemists (AOAC 1995). As outlined in (Bandara et al. 2017a), the moisture, crude ash, crude fat, crude fiber 
and crude protein contents were characterized. Total Soluble Sugars were analyzed by using the phenol-sulfuric acid method (Nielsen 2010).

\section{Extraction, Precipitation, and Characterization of melanin}

Extraction - Melanin was extracted from the dried, cultivated white strain of $A$. cornea samples containing 10-12\% moisture content by following the method used in Zou et al. (2010) with slight modifications. The basidiomes of A. cornea were pulverized and sieved through a 40mesh sieve. Approximately $6 \mathrm{~g}$ of powdered basidiome were washed with running water at a ratio of $30 \mathrm{ml} / \mathrm{g}$ (water/raw materials) for 5 minutes (min), followed by centrifugation at $4000 \mathrm{rpm}$ for 5 min. The supernatant was discarded and the precipitates were immersed in water. Then, the water/solid ratio was adjusted to $43 \mathrm{ml} / \mathrm{g}$ and the $\mathrm{pH}$ was adjusted to 12.0 with $1 \mathrm{M} \mathrm{NaOH}$. The suspension was placed in a brown bottle, which was placed in an ultrasonic instrument for ultrasound extraction at a power of $240 \mathrm{~W}$ and a temperature of $63^{\circ} \mathrm{C}$ for $40 \mathrm{~min}$. After that, each sample was centrifuged at $4000 \mathrm{rpm}$ for $5 \mathrm{~min}$ and the supernatant containing melanin was collected and stored at $4{ }^{\circ} \mathrm{C}$ in the dark.

Precipitation - The supernatant was adjusted to $\mathrm{pH} 2.0$ with $3 \mathrm{M} \mathrm{HCl}$ to precipitate melanin, followed by centrifugation at $4000 \mathrm{rpm}$ for $30 \mathrm{~min}$ at the room temperature. The supernatant was discarded and the precipitated melanin was washed successively with chloroform, ethyl acetate, and ethanol. Finally, the solid melanin was dissolved in $0.01 \mathrm{M} \mathrm{NaOH}$. The solution was stored in a brown bottle.

Characterization: An ultraviolet (UV) spectrophotometer (Shimadzu UV-2401PC) was used to record UV spectra of the melanin extracted from the samples and the synthetic melanin (Sigma Chemicals Co. St. Louis, USA).

\section{Quantification of melanin content}

Approximately $4 \mathrm{mg}$ of synthetic melanin (Shanghai Macklin Biochemical Co. Ltd, China) was weighed and dissolved in $100 \mathrm{ml} 0.01 \mathrm{M} \mathrm{NaOH}$ solution. Then, the stepwise dilution method was used to prepare five concentrations $(20 \mu \mathrm{g} / \mathrm{mL}, 16 \mu \mathrm{g} / \mathrm{ml}, 4 \mu \mathrm{g} / \mathrm{ml}, 1.6 \mu \mathrm{g} / \mathrm{ml}$ and $0.8 \mu \mathrm{g} / \mathrm{ml})$. Using $0.01 \mathrm{M} \mathrm{NaOH}$ solution as a blank control, the UV absorbance value was determined at 400 $\mathrm{nm}$. A standard curve was drawn (concentration vs absorbance) in Microsoft Excel to achieve the following formula: $\mathrm{y}=0.0116 \mathrm{x}+0.0401 ; \mathrm{R}^{2}=0.9983$. The melanin extracted from six mushroom samples was dissolved in 25, 30, 20, 25, 35, and $25 \mathrm{ml} 0.01 \mathrm{M} \mathrm{NaOH}$. Different sample solutions were determined using the UV spectrophotometer at $400 \mathrm{~nm}$ following the steps outlined above. Finally, the formula obtained using the standard curve was used to determine the content of melanin in different samples.

\section{Statistical analysis}

Thirty mushroom bags were used to determine basidiome production, and three replicates of brown and white strains of $A$. cornea samples from first three flushes were used for nutrient and melanin quantification analyses. The results were analyzed using $\mathrm{R}$ statistical software version 3.5.1 (RCoreTeam 2014) Welch's two sample t-tests were performed to observe whether there was a significant difference between the nutrient content of the dark brown and white A. cornea at $\mathrm{p}<$ 0.05 .

\section{Results}

\section{Morphological characteristics}

The morphological characteristics of the white strain of $A$. cornea are shown in Fig. 1 . The basidiome and internal features of white strain of A. cornea identified in this study are as follows:

Basidiome - 2-5 cm, short stalks, orbicular to cupulate to auriculiform; in fresh state abhymenial, hymenial surfaces white (4A1); in dry state abhymenial surface yellowish white (4A2); hymenial surface light yellow (4A4), ridges and veins present on abhymenial surface. 


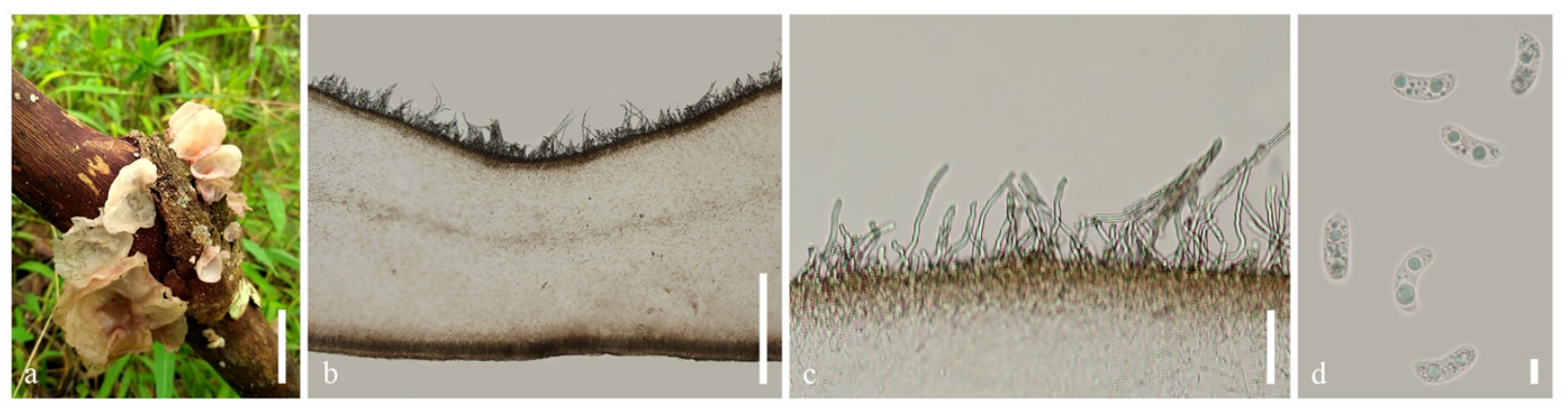

Fig. 1 - Photographs of white strain of Auricularia cornea (MFLU 190705). a Auricularia cornea growing on a decaying wood in the wild. b Cross-section of the basidiome. c Abhymenial hairs. d Basidiospores. Scale bars: $\mathrm{a}=3 \mathrm{~cm}, \mathrm{~b}=500 \mu \mathrm{m}, \mathrm{c}=100 \mu \mathrm{m}, \mathrm{d}=5 \mu \mathrm{m}$.

Internal features - thickness 920-1220 $\mu \mathrm{m}$; medulla present; abhymenial hairs densely arranged, fasciculated at the bottom, separated or clustered at the top, hyaline, tip blunt; clamp connections present; zona pilosa 100-230 $\mu \mathrm{m}$; zona compacta 20-30 $\mu \mathrm{m}$; zona subcompacta superioris 30-35 $\mu \mathrm{m}$; zona laxa superioris $295-330 \mu \mathrm{m}$; medulla 173-178 $\mu \mathrm{m}$; zona laxa inferioris 315-750 $\mu \mathrm{m}$; zona subcompacta inferioris 50-75 $\mu \mathrm{m}$; hymenium 80-90 $\mu \mathrm{m}$; basidia 55-66 × 3-4 $\mu \mathrm{m}$, cylindrical, blunt or tapered ends, sterigmata occasionally observed; basidiospores (12.3)13.6$15.5(17) \times(4.5) 4.9-5.6(6) \mu \mathrm{m}, \overline{\mathrm{x}} \pm \mathrm{SD}=14.5 \pm 0.97 \times 5.2 \pm 0.36 \mu \mathrm{m}, \mathrm{Q}=2.4-3.3(\mathrm{n}=30)$, allantoid, smooth, hyaline, with one large irregularly shaped guttule.

\section{Phylogeny}

43 ITS sequences which were identical to other sequences in the alignment were excluded from the maximum likelihood analysis. Strains corresponding to the excluded sequences were shown with equal (=) sign in Fig. 2. After identical sequences had been eliminated, 57 sequences were retained in the resulting ITS alignment. Nineteen terminal groups were obtained that corresponded to phylogenetic species in the analysis of ITS data (Fig. 2). Eighteen species were recovered as monophyletic. Auricularia delicata was found to be paraphyletic or polyphyletic. All cultivated strains of Auricularia from different countries were grouped into A. cornea or A. heimuer with moderate to strong bootstrap supports (Fig. 2). The ITS sequences of the white strain of Auricularia (V-11) were found to be exactly identical to Kun43, which is A. cornea (Fig. 2).

\section{Isolation, Spawn production, and Basidiome production}

The mycelium of the white strain of $A$. cornea was grown on sawdust mixed supplements medium ( $1 \mathrm{~kg}$ of medium per bag, 65\% moisture content) and was fully colonized within $52.9 \pm 1.2$ days. The average yield of the first three flushes on the sawdust mixed supplements medium was $57.6 \pm 5.6$ g. The biological efficiency was $16.5 \pm 1.2 \%$ (Fig. 3).

\section{Nutrient content}

The proximate composition, total soluble sugar content, and melanin content of the brown and white strains of $A$. cornea are summarized in Table 2.

\section{Characteristics and quantity of melanin found in Auricularia cornea}

The UV-visible absorption spectra (190-400 nm) of melanin solutions ( $\mathrm{pH} \mathrm{12)} \mathrm{isolated} \mathrm{from}$ A. cornea in contrast to the control synthetic melanin sample are shown in Fig. 4. The melanin extracted from basidiomes of $A$. cornea brown strain, white strain, and synthetic melanin each showed similar optical absorbance in a wide spectral range, as shown in Fig. 4. The quantification of melanin extracts from $A$. cornea samples indicated that they contained $<1.5 \mathrm{mg} / 100 \mathrm{~g}$ of melanin content. The melanin content of brown and white strain $A$. cornea was recorded as $0.46 \pm 0.37$ and $1.49 \pm 0.46 \mathrm{mg} / 100 \mathrm{~g}$ of dry weight, respectively. However, we did not observe any significant differences in melanin quantity between the brown and white strains. 


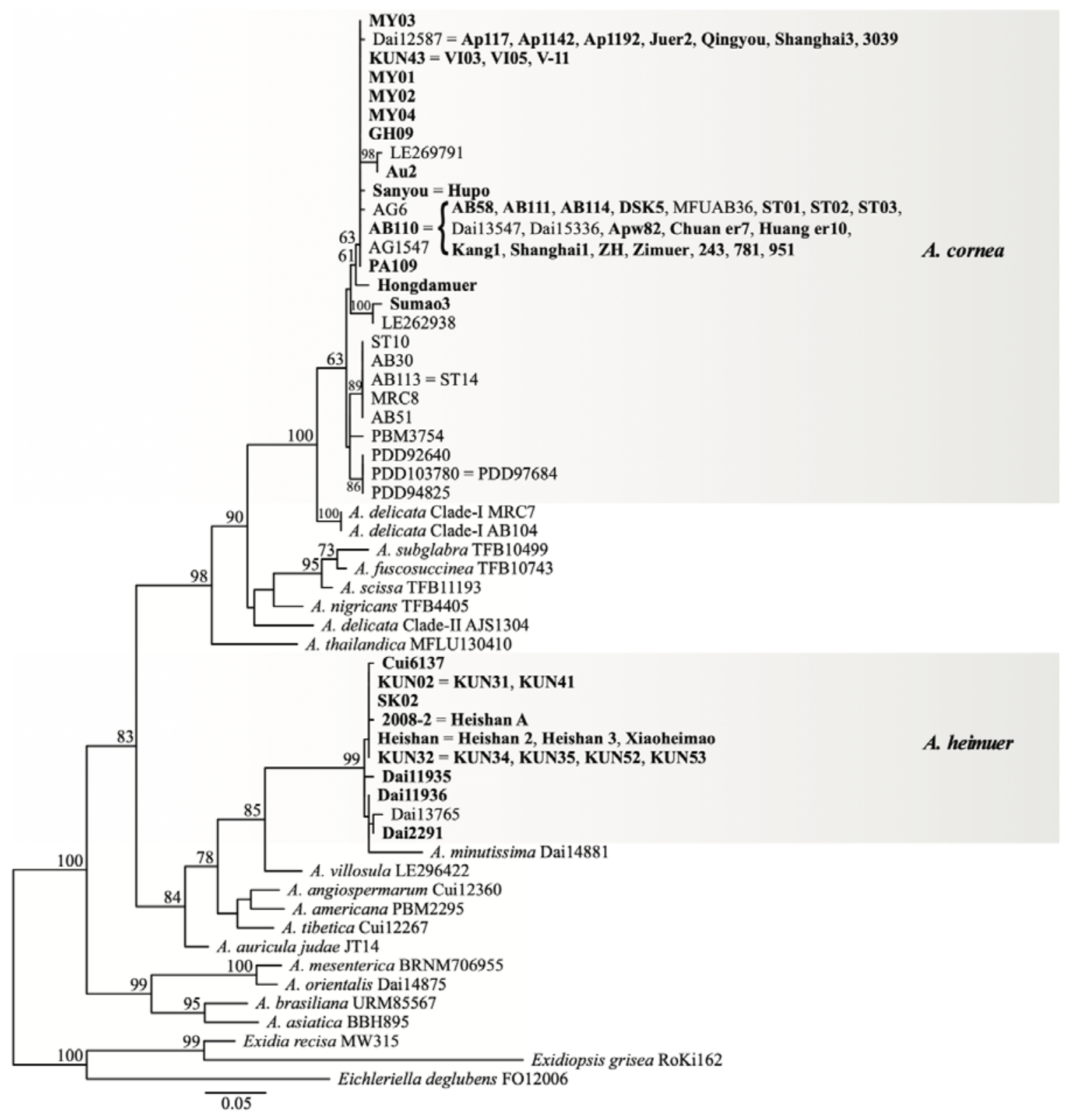

Fig. 2 - Phylograms inferred from maximum likelihood analyses of ITS sequences of Auricularia. Herbarium codes or collection codes are followed by species names. Cultivated strains are in bold. Bootstrap support values $>60 \%$ are displayed above each node. The tree is rooted with Eichleriella deglubens (FO12006), Exidia recisa (MW315), and Exidiopsis grisea (RoKi162).
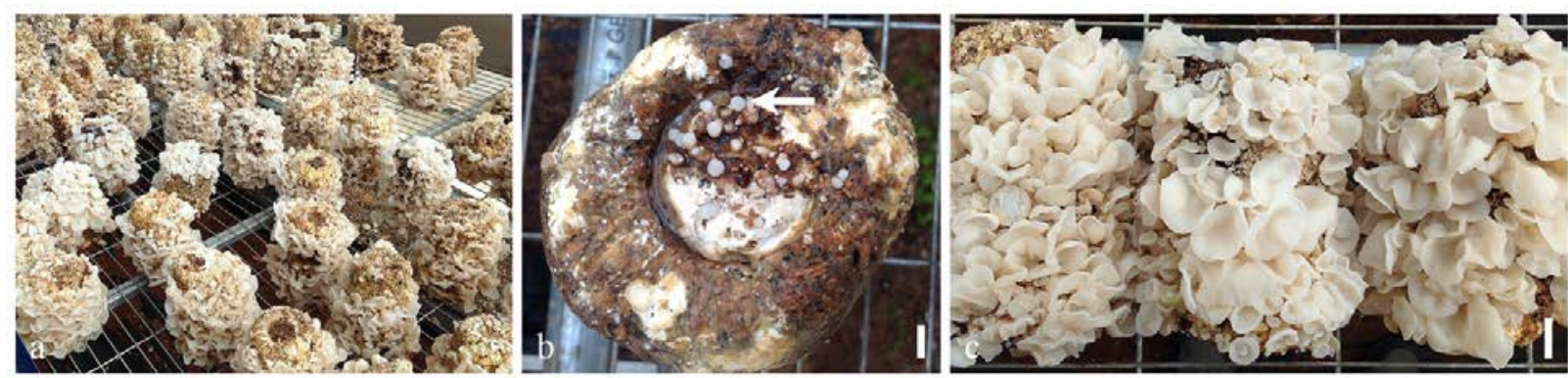

Fig. 3 - Structural differences of two developmental stages of cultivated white Auricularia cornea. a Cultivated basidiomes of white Auricularia cornea on sawdust medium. b The primordia stage. c The mature stage of basidiomes. Scale bars: $b=1 \mathrm{~cm}, c=2 \mathrm{~cm}$. The biological efficiency was calculated for these samples. 
Table 2 Proximate composition, total soluble sugar content (\% of dry weight) and melanin content (mg/100g) of basidiome of Auricularia cornea brown and white strains. Superscripts ( ${ }^{\mathrm{a}, \mathrm{b}}$ ) refer to significant differences between mean values determined at $\mathrm{p}<0.05$ using Welch's two sample ttests.

\begin{tabular}{lll}
\hline Nutrient constituent & Brown strain & White strain \\
\hline Moisture & $80.75 \pm 0.20^{\mathrm{w}}$ & $82.25 \pm 0.32^{\mathrm{w}}$ \\
Crude ash & $1.89 \pm 0.06^{\mathrm{a}}$ & $3.75 \pm 0.11^{\mathrm{b}}$ \\
Crude fat & $0.99 \pm 0.39^{\mathrm{a}}$ & $2.37 \pm 0.30^{\mathrm{b}}$ \\
Crude protein & $6.57 \pm 0.18^{\mathrm{a}}$ & $13.85 \pm 0.04^{\mathrm{b}}$ \\
Total dietary fiber & $87.47 \pm 0.26^{\mathrm{a}}$ & $72.57 \pm 0.23^{\mathrm{b}}$ \\
Total soluble sugar & $6.94 \pm 0.54^{\mathrm{a}}$ & $9.03 \pm 0.30^{\mathrm{b}}$ \\
Melanin & $0.46 \pm 0.37$ & $1.49 \pm 0.46$ \\
\hline
\end{tabular}

${ }^{\mathrm{w}}$ Represented as \% of fresh weight, protein conversion factor $(\mathrm{N} \times 6.25)$

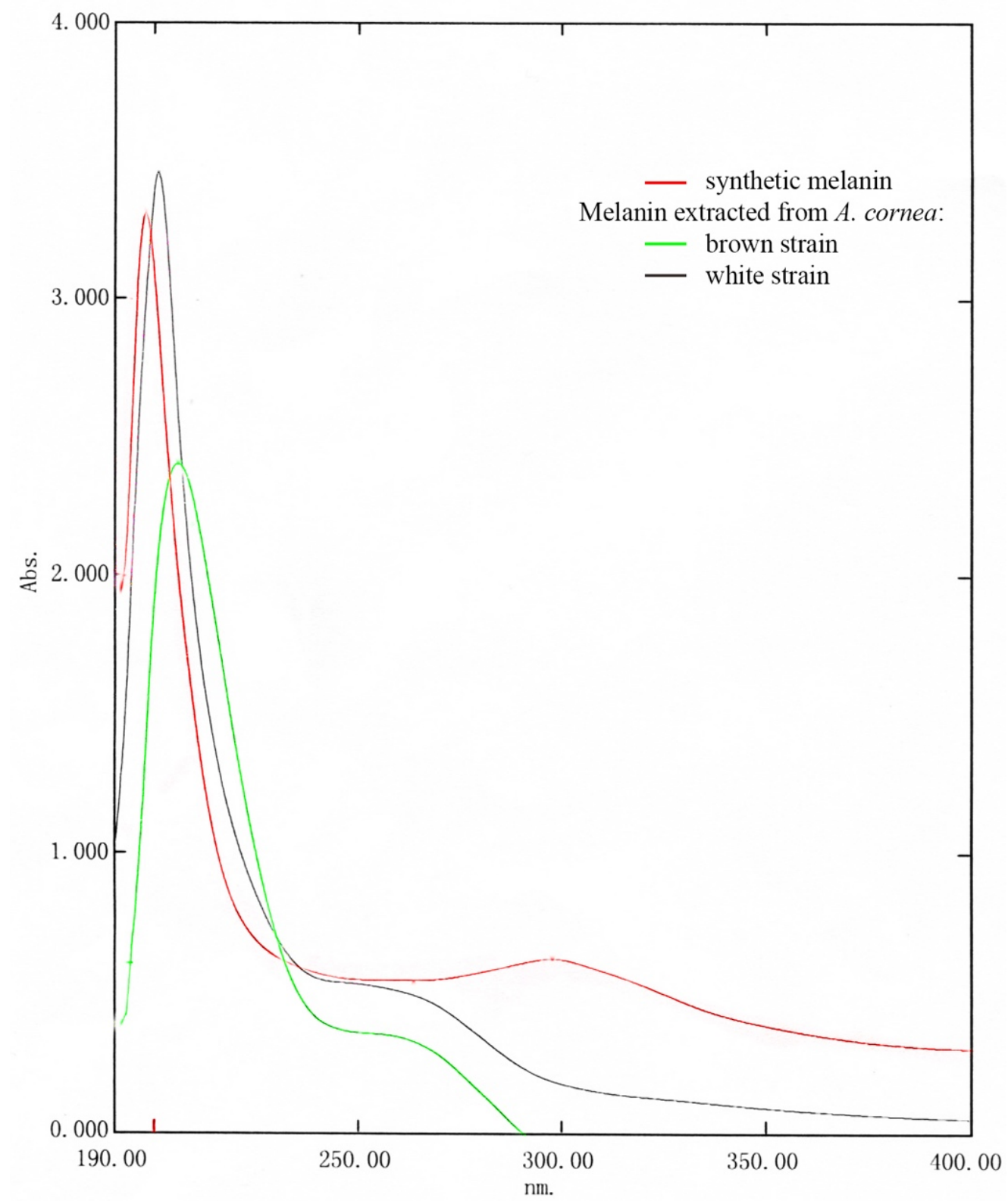

Fig. 4 - Comparison of ultraviolet-visible (UV) absorption spectra of synthetic melanin and melanin extracted from basidiomes of Auricularia cornea. The graph illustrates the UV absorption spectrums of synthetic melanin (red) and melanin extracted from basidiomes of Auricularia cornea brown strain (green) and white strain (blue). 


\section{Discussion}

In this study, a white strain of A. cornea collected from a forest in Thailand was successfully identified and domesticated. This is the first report of a white strain of A. cornea being domesticated from a tropical region, which has the potential to be cultivated in warm climatic conditions. Consistent yield of the white strain of $A$. cornea was achieved between bags under 200 bags of production. The biological efficiency of the white strain of $A$. cornea $(16.5 \pm 1.2 \%)$ was lower than that of the brown strains of $A$. cornea, which previously have been commercially cultivated (Tan et al. 2018). This difference in biological efficiency was likely due to the fact that the brown strains of $A$. cornea were cultivated on a substrate with optimum $\mathrm{C} / \mathrm{N}$ ratio, while the other required supplements which have been characterized previously (Tan et al. 2018). However, the white mutant of $A$. cornea gave a $12.4 \%$ higher yield compared with its purple black coloured wild-type grown in China (Wang et al. 2015). As we now have domesticated the white strain of $A$. cornea, this study provides the opportunity to further optimize its cultivation conditions and increase its biological efficiency for higher industrial quality.

The complete ITS region, including the ITS1, 5.8S and ITS2 of rDNA, was used in this study for the phylogenetic analysis of the white strain of $A$. cornea. ITS has been established as an adequate molecular marker for phylogenetic species delimitation in Auricularia that correspond with their morphology (Weiß \& Oberwinkler 2001, Looney et al. 2013, Malysheva \& Bulakh 2014, Wu et al. 2014b, Bandara et al. 2015). According to morphological characteristics (e.g. hyphal zonation, length of the abhymenial hairs) and rDNA ITS analysis of Auricularia samples collected from different countries in Asia, including the white strain, $A$. cornea is commercially cultivated in China, Indonesia, Myanmar, Philippines, South Korea, Thailand, Vietnam. However, in most studies, the cultivated varieties of $A$. cornea have been misidentified as A. polytricha (Yan et al. 2004, Yu et al. 2008, Du et al. 2011a, 2011b, Jia et al. 2011, Razak et al. 2013), which has been synonymized as A. nigricans (Looney et al. 2013).

Nutritional analysis conducted in this study shows that the white strain of $A$. cornea contains a significantly higher $(\mathrm{p}<0.05)$ proportion of fat, protein, and soluble sugars than the brown strain by dry weight, suggesting the potentially high demand for this strain. However, our analysis shows that the total dietary fiber content in the white strain of $A$. cornea is lower than that of the brown strain, which may limit its usability as a fiber-rich edible mushroom when compared to the brown strain. Previous studies have also demonstrated examples of white and brown strains of Auricularia sp. having different proximate contents. For example, significant higher contents of protein and fiber have been reported from the white strain of $A$. fuscosuccinea than its brown strain (Mau et al. 1998). Moreover, the fat quantities were similar on both brown and white strains of $A$. fuscosuccinea (Mau et al. 1998).

Mushrooms are highly valued as a good source of protein, which is an essential part of the human diet (Ingram 2002). The newly domesticated white strain of A. cornea mushroom contains higher amounts of protein than currently commercially cultivated Auricularia species (Crisan \& Sands 1978, Mau et al. 1998, Cao et al. 2017, USDA 2018a, 2018b). Lipid content of mushrooms is limited (2-6\%), due to a low total lipid content and a low proportion of desirable n-3 fatty acids (Kalac 2009). Compared to the commercially cultivated Auricularia species (Crisan \& Sands 1978, Mau et al. 1998, Cao et al. 2017, USDA 2018a, 2018b), the white strain of A. cornea domesticated in our study contained lower fat content. Therefore, the current study also contributes to the knowledge of the proximate content diversity of cultivated Auricularia in South Asia.

Edible mushrooms are rich in non-starch polysaccharides, which can be a good source of dietary fiber for humans (Cheung 2013). Most non-starch polysaccharides values were reported in the literature based on crude fiber content (Crisan \& Sands 1978, Aletor 1995, Mau et al. 1998, Bandara et al. 2017a). However, few studies have reported Auricularia species as having higher dietary fiber content than other edible mushrooms (Cheung 1997, 2013, Sekara et al. 2015). In this study, more than $70 \%$ of the dry weight of total dietary fiber content was reported from both white and brown strains of A. cornea. Therefore, A. cornea can be considered as an ideal source of dietary fiber, which can support health maintenance and disease prevention. Although a significantly 
higher quantity of total soluble sugar content was found in the A. cornea white strain than its brown strain, both strains are low in soluble sugars in contrast to the other edible Auricularia species (Mau et al. 1998, Kadnikova et al. 2015, Bandara et al. 2017a). The lower quantity of soluble sugars may result in mild taste differences in all edible Auricularia, including A. cornea. The genetic similarity coefficient was 0.636 between the white mutant and wild-type and 0.788 between the light brown mutant and its wild-type, which indicates a large genetic difference between the mutant and its wild-type (Wang et al. 2015)

The optical absorbance spectra for melanin extracted from $A$. cornea strains showed profiles quite similar to that of synthetic melanin, suggesting that the quality of the melanin extracted from the $A$. cornea strains were as high as the synthetic melanin. Previous studies have also shown similar UV-visible absorbance spectra from melanin extracts of A. auricula-judae (=A. auricula) (Zou et al. 2010, Sun et al. 2016b, Hou et al. 2019). The melanin quantity extracted appears to be dependent on the species. For instance, $120.05 \mathrm{mg} / 100 \mathrm{~g}$ of melanin could be yielded under optimized conditions from A. auricula-judae (Zou et al. 2010). Also, melanin quantity of $A$. auricula-judae affected by the substitute materials used for cultivation (Yao et al. 2019). As this is the first study which characterized the quantity of melanin in A. cornea, it is unknown whether the lower melanin content observed in the study was due to actually lower melanin content compared to other Auricularia sp. or due to the substitute materials used for cultivation. Nevertheless, this study provides the ground for further optimization of the melanin extraction conditions for future studies.

\section{Acknowledgements}

Asanka R. Bandara would like to thank China Postdoctoral Science Foundation for funding his postdoctoral project. Peter E. Mortimer would like to thank the National Science Foundation of China and the South East Asian Biodiversity resources Institute, Chinese Academy of Sciences, for financial support under the following grants: 41761144055, 41771063, Y4ZK111B01. Samantha C. Karunarathna would like to thank the CAS President's International Fellowship Initiative (PIFI) young staff under the grant number: 2020FYC0002 and the National Science Foundation of China (NSFC) project code 31750110478 for funding this work. K.D. Hyde would like to thank the Thailand Research Fund for the grant "Domestication and bioactive evaluation of Thai Hymenopellis, Oudemansiella, Xerula and Volvariella species (basidiomycetes)" Grant No.: DBG6180033 for funding this work. K.D. Hyde would also like to thank the Thailand Science Research and Innovation (TSRI) grant, Macrofungi diversity research from the Lancang-Mekong Watershed and surrounding areas (Grant No. DBG6280009).

\section{References}

Aletor VA. 1995 - Compositional studies on edible tropical species of mushrooms. Food Chemistry 54, 265-268.

AOAC. 1995 - Official methods of Analysis of the Association of Official Analytical Chemist. 16th edn. Association of Official Analytical Chemists, Washington, DC.

Bandara AR, Chen J, Karunarathna S, Hyde KD et al. 2015 - Auricularia thailandica sp. nov. (Auriculariaceae, Auriculariales) a widely distributed species from Southeastern Asia. Phytotaxa 208, 147-156.

Bandara AR, Karunarathna SC, Mortimer PE, Hyde KD et al. 2017a - First successful domestication and determination of nutritional and antioxidant properties of the red ear mushroom Auricularia thailandica (Auriculariales, Basidiomycota). Mycological Progress 16, 1029-1039.

Bandara AR, Karunarathna SC, Phillips AJ, Mortimer PE et al. 2017b - Diversity of Auricularia (Auriculariaceae, Auriculariales) in Thailand. Phytotaxa 292, 19-34. 
Bandara AR, Rapior S, Mortimer PE, Kakumyan P et al. 2019 - A review of the polysaccharide, protein and selected nutrient content of Auricularia, and their potential pharmacological value. Mycosphere 10, 579-607.

Bin L, Wei L, Xiaohong C, Mei J et al. 2012 - In vitro antibiofilm activity of the melanin from Auricularia auricula, an edible jelly mushroom. Annals of Microbiology 62, 1523-1530.

Cao Y, Bao H, Li X, Bau T et al. 2017 - Anti-tumor activities of Auricularia cornea fruiting body extract in H22 bearing mice. Mygosystema 36, 1289-1298.

Chang ST, Miles PG. 2004 - Mushrooms: Cultivation, nutritional value, medicinal effect, and environmental impact. 2nd edn. CRC Press, Boca Raton, Florida, pp 480.

Cheung PCK. 1997 - Dietary fibre content and composition of some edible fungi determined by two methods of analysis. Journal of the Science of Food and Agriculture 73, 255-260.

Cheung PCK. 2013 - Mini-review on edible mushrooms as source of dietary fiber: Preparation and health benefits. Food Science and Human Wellness 2, 162-166.

Crisan EV, Sands A. 1978 - Nutritional Value. In: Chang S T, Hayes W A (eds) The Biology and Cultivation of Edible Mushrooms. Academic Press, New York, pp 137-168.

De Souza RA, Kamat NM, Nadkarni VS. 2018 - Purification and characterisation of a sulphur rich melanin from edible mushroom Termitomyces albuminosus Heim. Mycology 9, 296-306.

Dikeman CL, Bauer LL, Flickinger EA, Fahey GC. 2005 - Effects of stage of maturity and cooking on the chemical composition of select mushroom varieties. Journal of Agricultural and Food Chemistry 53, 1130-1138.

Du P, Cui B, Dai Y. 2011a - Genetic diversity of wild Auricularia polytricha in Yunnan province of South-western China revealed by sequence-related amplified polymorphism (SRAP) analysis. Journal of Medicinal Plants Research 5, 1374-1381.

Du P, Cui BK, Dai YC. 2011b - High genetic diversity in wild culinary-medicinal wood ear mushroom, Auricularia polytricha (Mont.) Sacc., in tropical China revealed by ISSR analysis. International Journal of Medicinal Mushrooms 13, 289-297.

Fuller R, Buchanan P, Roberts M. 2005 - Medicinal uses of fungi by New Zealand Maori people. International Journal of Medicinal Mushrooms 7, 402.

Hou RL, Liu X, Yan JJ, Xiang KK et al. 2019 - Characterization of natural melanin from Auricularia auricula and its hepatoprotective effect on acute alcohol liver injury in mice. Food \& Function 10, 1017-1027.

Ingram S. 2002 - The real nutritional value of fungi. United Kingdom: Cancer Research UK.

Jia DH, Wang B, Peng WH, Gan BC et al. 2011 - Analysis on 22 Auricularia polytricha strains using ITS sequencing. Southwest China Journal of Agricultural Sciences 24, 181-184.

Jolivet S, Arpin N, Wichers HJ, Pellon G. 1998 - Agaricus bisporus browning: a review. Mycological Research 102, 1459-1483.

Kadnikova IA, Costa R, Kalenik TK, Guruleva ON et al. 2015 - Chemical composition and nutritional value of the mushroom Auricularia auricula-judae. Journal of Food and Nutrition Research 3, 478-482.

Kalac P. 2009 - Chemical composition and nutritional value of European species of wild growing mushrooms: A review. Food Chemistry 113, 9-16.

Kim H, Hur W, Lee S. 2009 - Isolation and Characterization of Dark Brownish Pigments from Fruit Body of Auricularia auricula. Food Engineering Progress 13, 282-288.

Kobayashi Y. 1981 - The genus Auricularia. Bulletin of the National Science Museum, Tokyo 7, 41-67.

Lampman AM. 2007 - Ethnomycology: Medicinal and edible mushrooms of the Tzeltal Maya of Chiapas, México. International Journal of Medicinal Mushrooms 9, 1-5.

Liang CH, Wu CY, Lu PL, Kuo YC et al. 2019 - Biological efficiency and nutritional value of the culinary-medicinal mushroom Auricularia cultivated on a sawdust basal substrate supplement with different proportions of grass plants. Saudi Journal of Biological Sciences 26, 263-269. 
Lin WY, Yang MJ, Hung LT, Lin LC. 2013 - Antioxidant properties of methanol extract of a new commercial gelatinous mushrooms (white variety of Auricularia fuscosuccinea) of Taiwan. African Journal of Biotechnology 12, 6210-6221.

Looney BP, Birkebak JM, Matheny PB. 2013 - Systematics of the genus Auricularia with an emphasis on species from the southeastern United States. North American Fungi 8, 1-25.

Lowy B. 1952 - The genus Auricularia. Mycologia 44, 656-692.

Lucier G, Allshouse JE, Lin BH. 2003 - Factors affecting US mushroom consumption. USDA Economic Research Service, Washington, D.C., pp 11.

Malysheva VF, Bulakh EM. 2014 - Contribution to the study of the genus Auricularia (Auriculariales, Basidiomycota) in Russia. Novosti Sistematiki Nizshikh Rastenii 48, 164180.

Mau JL, Wu KT, Wu YH, Lin YP. 1998 - Nonvolatile taste components of ear mushrooms. Journal of Agricultural and Food Chemistry 46, 4583-4586.

Mendoza CG, Leal JA, Novaes-Ledieu M. 1979 - Studies of the spore walls of Agaricus bisporus and Agaricus campestris. Canadian Journal of Microbiology 25, 32-39.

Nielsen SS. 2010 - Phenol-sulfuric acid method for total carbohydrates. In: Nielsen S S (ed) Food Analysis Laboratory Manual. Springer, Boston, MA, pp 47-53.

OECD. 2007 - (Organisation for Economic Co-operation Development) Environment, halth and safety publications - Consensus document on compositional considerations for new varieties of the cultivated mushroom Agaricus bisporus: key food and feed nutrients, anti-nutrients and toxicants. Safety of Novel Foods and Feeds. OECD, Paris.

Phillips KM, Ruggio DM, Horst RL, Minor B et al. 2011 - Vitamin D and sterol composition of 10 types of mushrooms from retail suppliers in the United States. Journal of Agricultural and Food Chemistry 59, 7841-7853.

Prados-Rosales R, Toriola S, Nakouzi A, Chatterjee S et al. 2015 - Structural characterization of melanin pigments from commercial preparations of the edible mushroom Auricularia auricula. Journal of Agricultural and Food Chemistry 63, 7326-7332.

Razak DLA, Abdullah N, Johari NMK, Sabaratnam V. 2013 - Comparative study of mycelia growth and sporophore yield of Auricularia polytricha (Mont.) Sacc. on selected palm oil wastes as fruiting substrate. Applied Microbiology and Biotechnology 97, 3207-3213.

RCoreTeam. 2014 - R: A language and environment for statistical computing. R Foundation for Statistical Computing, Vienna, Austria.

Royse DJ, Baars J, Tan Q. 2017 - Current overview of mushroom production in the world. In: Zied D C, Giménez A P (eds) Edible and medicinal mushrooms: Technology and applications. John Wiley \& Sons Ltd, West Sussex, UK, pp 5-13.

Sekara A, Kalisz A, Grabowska A, Siwulski M. 2015 - Auricularia spp. - mushrooms as novel food and therapeutic agents - a review. Sydowia 67, 1-10.

Selvakumar P, Rajasekar S, Periasamy K, Raaman N. 2008 - Isolation and characterization of melanin pigment from Pleurotus cystidiosus (telomorph of Antromycopsis macrocarpa). World Journal of Microbiology and Biotechnology 24, 2125-2131.

Sierra S, Cifuentes J, Ruan-Soto F, Mariaca R. 2008 - An albino form of Auricularia fuscosuccinea from Lacandonia tropical forest, Chiapas, Mexico. Mycotaxon 105, 415-419.

Silvestro D, Michalak I. 2012 - raxmlGUI: A graphical front-end for RAxML. Organisms Diversity \& Evolution 12, 335-337.

Stamets P. 2000 - Growing gourmet and medicinal mushrooms. 3rd edn. Ten Speed Press, Berkeley, California, pp 574.

Sun S, Zhang X, Chen W, Zhang L et al. 2016a - Production of natural edible melanin by Auricularia auricula and its physicochemical properties. Food Chemistry 196, 486-492.

Sun SJ, Zhang XJ, Sun SW, Zhang LY et al. 2016b - Production of natural melanin by Auricularia auricula and study on its molecular structure. Food Chemistry 190, 801-807.

Tan W, Miao R, Zhou J, Li X et al. 2018 - Advances in cultivation techniques of Auricularia cornea. Acta Edulis Fungi 25, 1-12. 
Tang B, Shi J. 2014 - Research of extraction and antioxidant activities of melanin in Auricularia polytricha from Qin-ba mountain area. Science and Technology of Food Industry 35, 85-89.

Thaithatgoon P, Thaithatgoon B, Boonkemthong C, Tanticharoen M et al. 2004 - Edible mushrooms. In: Jones E B G, Tantichareon M, Hyde K D (eds) Thai Fungal Diversity. National Center for Genetic Engineering and Biotechnology (BIOTEC), Thailand, pp 241251.

USDA. 2018a - (United States Department of Agriculture) Agricultural Research Service Full Report (All Nutrients): 11228, Jew’s ear, (pepeao), raw. National Nutrient Database for Standard Reference Legacy, The National Agricultural Library, USDA. https://ndb.nal.usda.gov/. Accessed 2018, April 11

USDA. 2018b - (United States Department of Agriculture) Agricultural Research Service Full Report (All Nutrients): 11988, Fungi, Cloud ears, dried. National Nutrient Database for Standard Reference Legacy, The National Agricultural Library, USDA. https://ndb.nal.usda.gov/. Accessed 2018, April 11

Wang B, Jia D, Gao J, Xian L et al. 2015 - Study on Genetic Differences and Yields within Auricularia cornea Mutants. Southwest China Journal of Agricultural Sciences 28, 28322834.

Weiß M, Oberwinkler F. 2001 - Phylogenetic relationships in Auriculariales and related groupshypotheses derived from nuclear ribosomal DNA sequences. Mycological Research 105, 403-415.

White TJ, Bruns T, Lee S, Taylor J. 1990 - Amplification and direct sequencing of fungal ribosomal RNA genes for phylogenetics. In: Innis MA, Gelfand DH, Sninsky JJ, White TJ (eds) PCR protocols: a guide to methods and applications, vol 18. Academic Press, San Diego, California, pp 315-322.

Williams SE, Bunyard B, Sturgeon W. 2014 - Wild mushrooms. College of Food, Agricultural and Environmental Sciences, Ohio State University.

https://ohioline.osu.edu/factsheet/plpath-gen-11. Accessed June 18, 2019

Wong G. 1989 - Compatibility and fruiting studies of an albino form of Auricularia cornea. Mycotaxon 34, 259-266.

Wu F. 2016 - Taxonomy and phylogeny of Auricularia (Auriculariales, Basidiomycota). http://www.ncbi.nlm.nih.gov/popset/?term=KX022016. Accessed July 06, 2019

Wu F, Yuan Y, He SH, Bandara AR et al. 2015a - Global diversity and taxonomy of the Auricularia auricula-judae complex (Auriculariales, Basidiomycota). Mycological Progress 14, 1-16.

Wu F, Yuan Y, Liu HG, Dai YC. 2014a - Auricularia (Auriculariales, Basidiomycota): a review of recent research progress. Mycosystema 33, 198-207.

Wu F, Yuan Y, Malysheva VF, Du P et al. 2014b - Species clarification of the most important and cultivated Auricularia mushroom "Heimuer": evidence from morphological and molecular data. Phytotaxa 186, 241-253.

Wu F, Yuan Y, Rivoire B, Dai YC. 2015b - Phylogeny and diversity of the Auricularia mesenterica (Auriculariales, Basidiomycota) complex. Mycological Progress 14, 1-9.

Wu Z, Zhang M, Yang H, Zhou H et al. 2018 - Production, physico-chemical characterization and antioxidant activity of natural melanin from submerged cultures of the mushroom Auricularia auricula. Food Bioscience 26, 49-56.

Yan PS, Luo XC, Zhou Q. 2004 - RAPD molecular differentiation of the cultivated strains of the jelly mushrooms, Auricularia auricula and A. polytricha. World Journal of Microbiology and Biotechnology 20, 795-799.

Yao H, Liu Y, Ma ZF, Zhang H et al. 2019 - Analysis of Nutritional Quality of Black Fungus Cultivated with Corn Stalks. Journal of Food Quality 2019, 5.

Yu M, Ma B, Luo X, Zheng L et al. 2008 - Molecular diversity of Auricularia polytricha revealed by inter-simple sequence repeat and sequence-related amplified polymorphism markers. Current Microbiology 56, 240-245. 
Zhang JX, Chen Q, Huang CY, Gao W et al. 2015 - History, current situation and trend of edible mushroom industry development. Mycosystema 34, 524-540.

Zou Y, Xie C, Fan G, Gu Z et al. 2010 - Optimization of ultrasound-assisted extraction of melanin from Auricularia auricula fruit bodies. Innovative Food Science and Emerging Technologies 11, 611-615.

Zou Y, Yang Y, Zeng B, Gu Z et al. 2013 - Comparison of physicochemical properties and antioxidant activities of melanins from fruit-bodies and fermentation broths of Auricularia auricula. International Journal of Food Properties 16, 803-813. 